\title{
Historic retreat of Grand Pacific and Melbern Glaciers, Saint Elias Mountains, Canada: an analogue for decay of the Cordilleran ice sheet at the end of the Pleistocene?
}

\author{
John J. Glague \\ Geological Survey of Canada, West Pender Street, Vancouver, British Columbia V6B 1R8, Canada, and \\ Institute for Quaternary Research, Simon Fraser University, Burnaby, British Columbia V5A 1S6, Canada \\ S. G. Evans \\ Geological Survey of Canada, 601 Booth Street, Ottawa, Ontario K1A 0E8, Canada
}

\begin{abstract}
Grand Pacific and Melbern Glaciers, two of the largest valley glaciers in British Columbia, have decreased over $50 \%$ in volume in the last few hundred years (total ice loss $=250-300 \mathrm{~km}^{3}$ ). Melbern Glacier has thinned $300-$ $600 \mathrm{~m}$ and retreated $15 \mathrm{~km}$ during this period; about $7 \mathrm{~km}$ of this retreat occurred between the mid-1970s and 1987, accompanied by the formation of one of the largest, presently existing, ice-dammed lakes on Earth. Grand Pacific Glacier, which terminates in Tarr Inlet at the British Columbia-Alaska boundary, retreated $24 \mathrm{~km}$ between 1879 and 1912. This rapid deglaciation has destabilized adjacent mountain slopes and produced spectacular ice-marginal land forms. The sediments and land forms produced by historic deglaciation in Melbern-Grand Pacific valley are comparable, both in style and scale, to those associated with the decay of the Cordilleran ice sheet at the end of the Pleistocene (c. 14-10 ka BP). Rates of historic and terminal Pleistocene deglaciation also may be comparable.
\end{abstract}

\section{INTRODUCTION}

Most glaciers in mountainous regions of the world have receded substantially during the last 100 years, probably in response to climatic warming (Hansen and Lebedeff, 1987; Houghton and others, 1990). Today, surfaces of alpine glaciers lie below Little Ice Age trim lines and their termini, in many cases, are up-valley of Little Ice Age end moraines.

In the Saint Elias Mountains of southeast Alaska, northwest British Columbia and southwest Yukon Territory, recent deglaciation has been accompanied by destabilization of formerly ice-covered, steep rock slopes, mass wasting of drift and increased sediment supply to streams issuing from glaciers. In addition, significant isostatic rebound is occurring in areas where ice losses have been particularly large, for example, some inlets and bays in southeast Alaska (Hicks and Shofnos, 1965; Hudson and others, 1982). Furthermore, Meier (1984) has suggested that the melting of glaciers outside Greenland and Antarctica accounts for one-third to

Fig. 1. Map of the study area showing the extent of $\triangleright$ glaciers in the 1970s, prior to the formation of glacial Lake Melbern (cf. Fig. 2). The Little Ice Age limit is indicated by thick solid lines. The dotted line marks the ice divide at Grand Pacific Pass and arrows indicate ice-flow directions. Topographic profiles $A A^{\prime}, B B^{\prime}$ and $C C^{\prime}$ are shown in Figure 5. one-half of the observed rise in sea level in the 20th century and that more than one-third of this meltwater has come from glaciers in the mountains bordering the Gulf of Alaska.

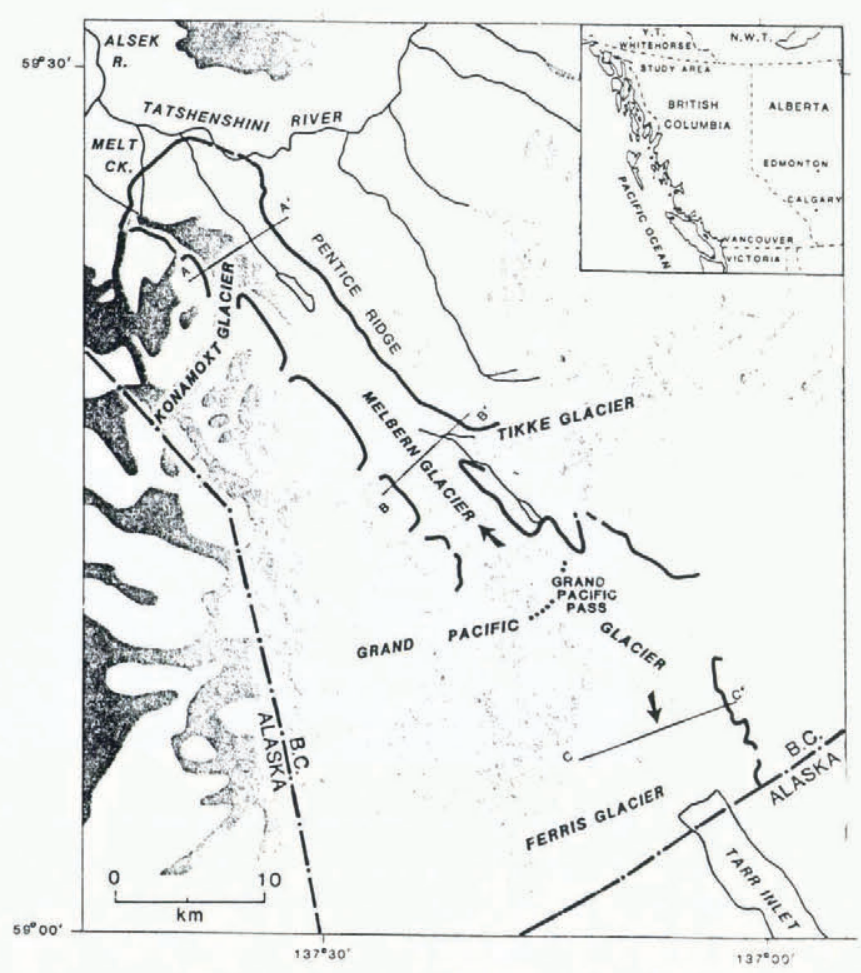


This paper documents an example of historic, largescale deglaciation in the Saint Elias Mountains of British Columbia and Alaska, specifically in Melbern Valley and Tarr Inlet (Fig. 1). The documentation is based largely on an analysis of late 19th and early 20th century survey data (International Boundary Commission, 1952), inspection of aerial photographs taken in 1979 and 1987, and field work conducted in 1991. In addition, we explore an analogy between deglaciation of this area over the last few hundred years and the disappearance of the Cordilleran ice sheet at the end of the Pleistocene.

\section{THE GRAND PACIFIC GLACIER - MELBERN GLAGIER SYSTEM}

Grand Pacific Glacier, with a length of $55 \mathrm{~km}$ and width of $2-5 \mathrm{~km}$, is one of the largest valley glaciers in British Columbia (Fig. 1). It flows north and east from source areas at $1500-3000 \mathrm{~m}$ elevation in the Saint Elias Mountains near the British Columbia-Alaska boundary and bifurcates into two large ice tongues at Grand Pacific Pass. One of the tongues, Melbern Glacier, flows $20 \mathrm{~km}$ northwest towards Tatshenshini River and presently terminates in a glacial lake at about $250 \mathrm{~m}$ a.s.l. The other tongue, Grand Pacific Glacier proper, terminates at tide water in Tarr Inlet, $18 \mathrm{~km}$ southeast of Grand Pacific Pass.

\section{Decay of Melbern Glacier}

A conspicuous vegetation trim line and associated fresh lateral and end moraines delineate the margins of Melbern Glacier at the maximum of the Little Ice Age. At that time, Melbern Glacier terminated about $15 \mathrm{~km}$ northwest of its present position, was confluent with its two largest tributaries, Konamoxt and Tikke Glaciers,

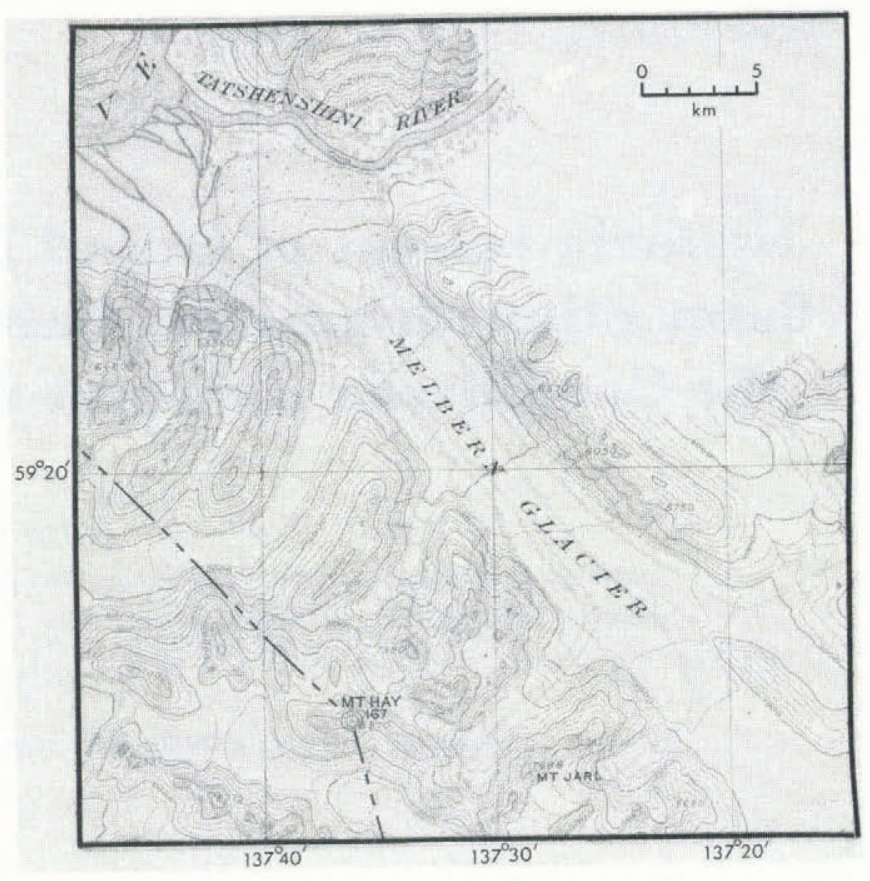

Fig. 2. Part of an international-boundary survey map (International Boundary Commission, 1928) showing the approximate extent of Melbern Glacier in 1908 ( $c f$. Fig. 1). Comparison of this map and a 1908 photograph of the same area (Fig. 3) suggests that Melbern Glacier may not have extended quite as far north in 1908 as is shown on the map, i.e. part of the glacier terminus immediately south of Tatshenshini River, which is shown on the map as being debris-covered, may have disappeared before this date. Map reproduced by permission of International Boundary Commission (1928).

and was 300-600 m thicker than today (Fig. 1). A comparison of the extent of the glacier at that time, in 1908 when Melbern Glacier was photographed during an

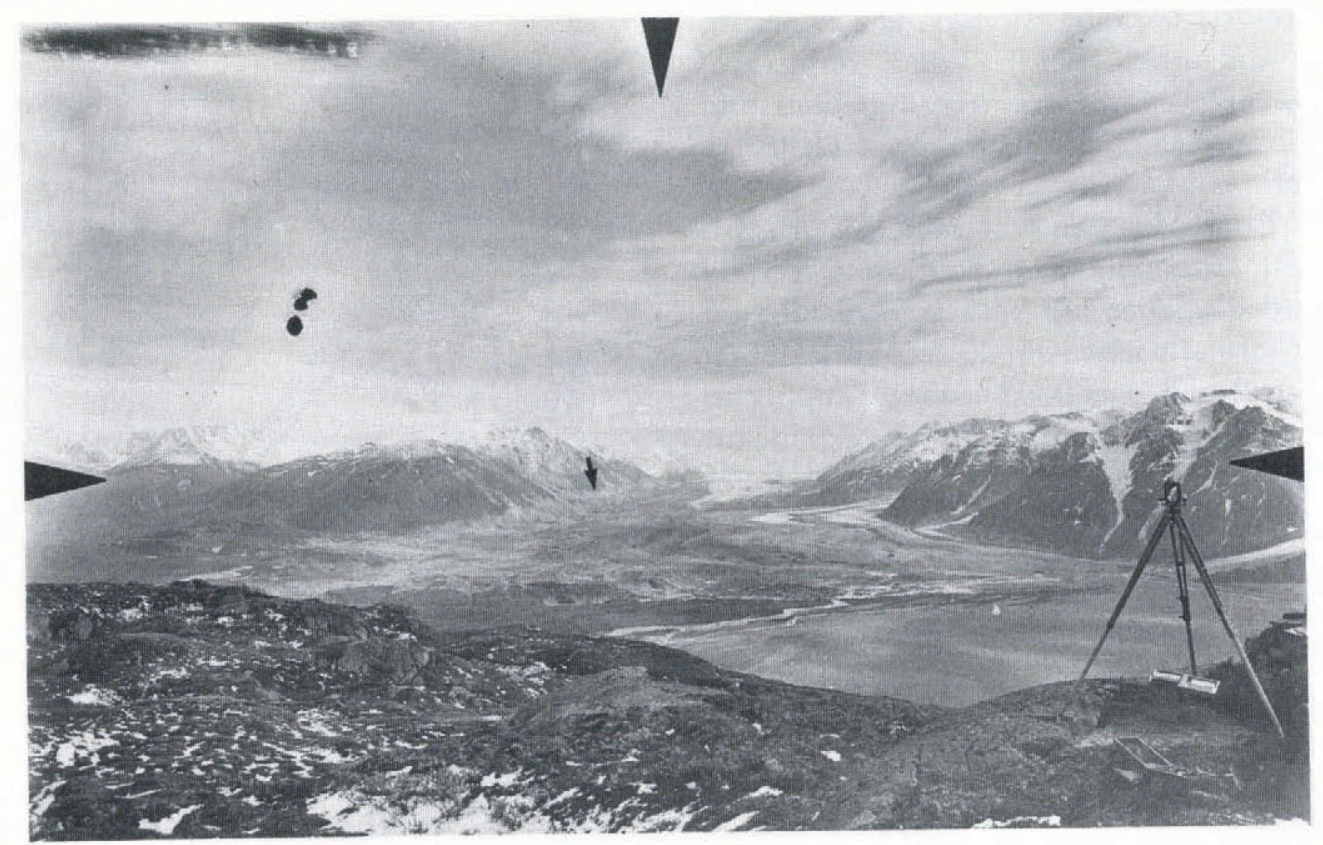

Fig. 3. Melbern Glacier in 1908; view to the southeast from a ridge near Alsek River. At this time, the debris-covered northern margin of the glacier was less than $2 \mathrm{~km}$ from the Little Ice Age end moraine. Note, however, that the surface of Melbern Glacier is well below the conspicuous Little Ice Age trim line (arrow). (Photograph by G. White-Fraser (photograph station CYR; \#46); courtesy of International Boundary Commission, Ottawa, Canada.) 
Clague and Evans: Retreat of Grand Pacific and Melbern Glaciers, St. Elias Mountains, Canada

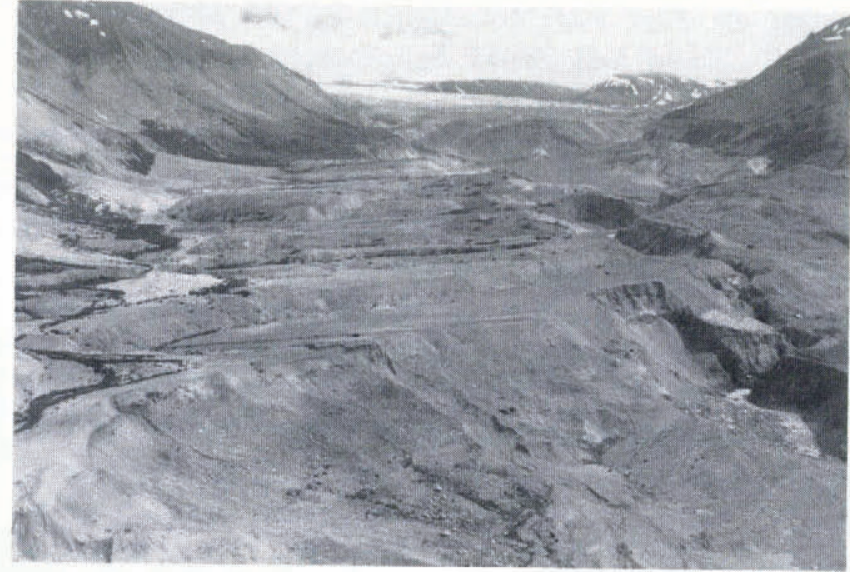

Fig. 4. Oblique aerial photograph, taken in 1991, of a flight of kame terraces and kame deltas along Tikki Creek east of Melbern Glacier; view east from above Melbern Glacier. These land forms record down-wasting of Melbern Glacier since the early 20th century.

international boundary survey (Figs 2 and 3 ) and in 1991 , indicates that at least $50 \mathrm{~km}^{3}$ of ice has been lost in Melbern Valley north of Grand Pacific Pass in the last few hundred years.

Thinning and retreat since the Little Ice Age maximum is recorded by a classical staircase-like series of kame terraces and kame deltas along Tikke Creek (Figs 4 and 5) and by shore lines and thick drift which are particularly prominent on the northeast side of the valley
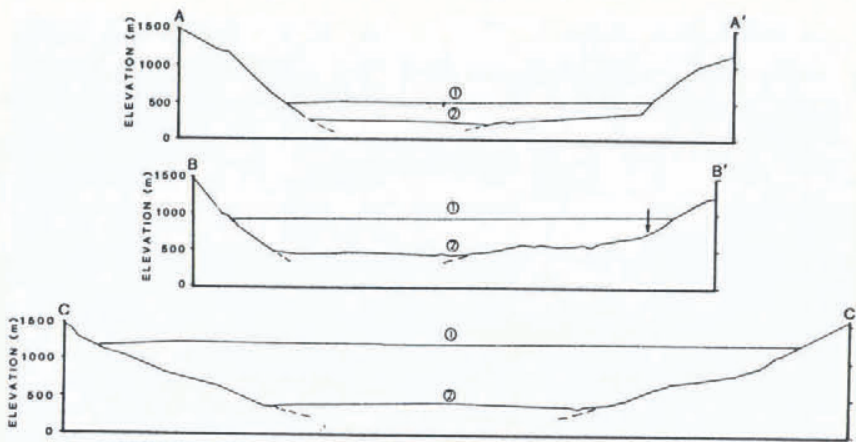

Fig. 5. Topographic profiles across Melbern-Grand Pacific Valley showing thinning that has occurred between the maximum of the Little Ice Age (surface 1) and 1979 (surface 2). The upper limit of the Tikki Creek kame terraces and kame deltas on profile $B B^{\prime}$ is indicated by an arrow. See Figure 1 for the locations of the profiles. Sources of information: 1979 ice surface $-1: 50000$ scale topographic maps derived from 1979 air photographs; Little Ice Age maximum-trim line on 1979 air photographs.

below Pentice Ridge (Fig. 1). As deglaciation progressed, lakes were trapped between Melbern Glacier and the walls of the valley; the level of these lakes fell as the glacier thinned. Kame terraces and deltas were built below Tikke Glacier as it separated from Melbern Glacier and retreated eastward. Successively lower terraces record progressive thinning of Melbern Glacier and the related fall in the level of the ice-marginal lake in this area.

Air-photograph analysis indicates that, shortly before

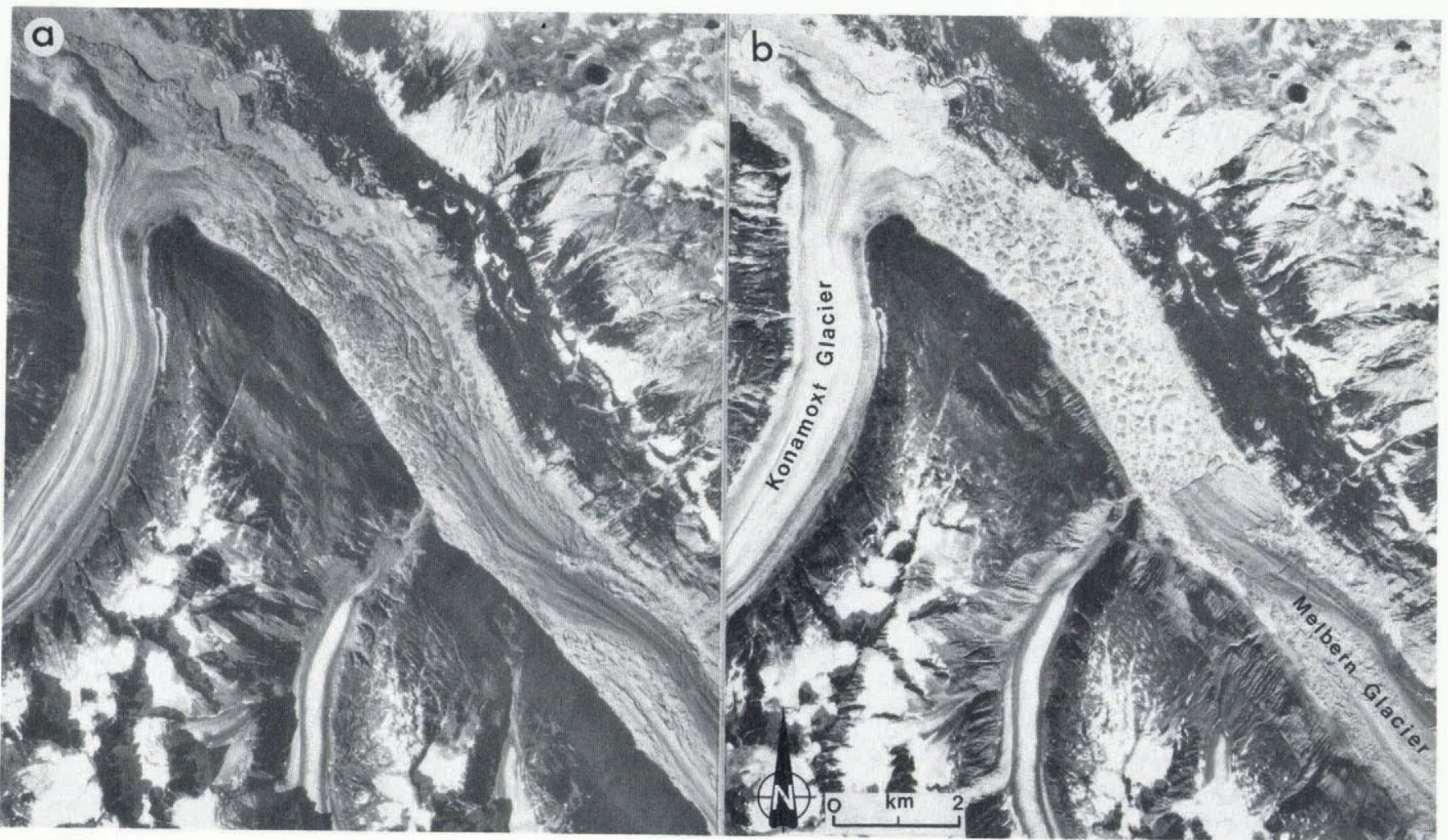

Fig. 6. Aerial photographs of Melbern and Konamoxt Glaciers in (a) 1979 (A25292-183; Energy Mines and Resources Canada) and (b) 1987 (BC87076-268; Province of British Columbia). Note that glacial Lake Melbern is just beginning to form in 1979 as dead ice between the two glaciers floats and breaks up. The lake is fully developed in 1987, although it is charged with tabular icebergs up to $200 \mathrm{~m}$ across. 


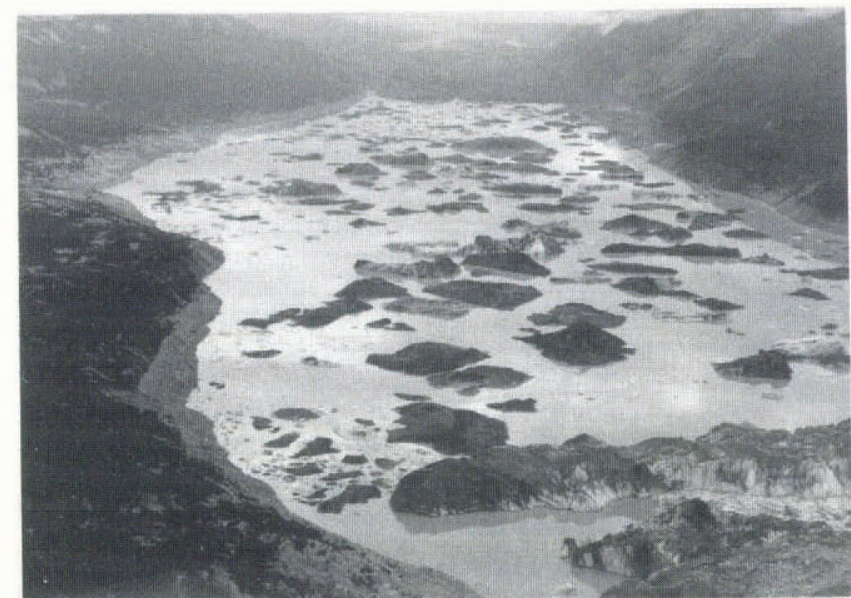

Fig. 7. Glacial Lake Melbern, July 1991; oblique aerial view to the south from the vicinity of Konamoxt Glacier. The conspicuous shoreline about $35-40 \mathrm{~m}$ above the lake shore dates to the late 1970s.

1979 (Fig. 6a), the lower part of Melbern Glacier stagnated, floated and began to disintegrate into complex tabular masses of ice enveloped by the waters of what were soon to become one of the largest glacial lakes on Earth ("glacial Lake Melbern"). By 1987, the front of Melbern Glacier had receded $7 \mathrm{~km}$ and glacial Lake Melbern covered $12 \mathrm{~km}^{2}$ of the valley bottom behind the stagnant toe of Konamoxt Glacier (Figs 6b and 7).

Glacial Lake Melbern overflows along the northeast side of Konamoxt Glacier into Tatshenshini River. Initially, the lake was $40-50 \mathrm{~m}$ higher than the flood plain immediately below the Konamoxt Glacier ice dam. Between 1979 and 1987, however, the level of the lake dropped due to retreat of Konamoxt Glacier and related incision of the outlet; in 1991, the lake was only $10-20 \mathrm{~m}$ higher than the downstream end of the overflow channel. With any further retreat, the lake will cease to be dammed by Konamoxt Glacier but will extend another $8 \mathrm{~km}$ northward to the head of Melt Creek (Fig. 1), attaining an overall length of $15 \mathrm{~km}$. Thereafter, the level of the lake may gradually drop as the outlet stream incises the morainal and alluvial plain sloping north to Tatshenshini and Alsek Rivers.

\section{Decay of Grand Pacific Glacier}

Historic decay of Grand Pacific Glacier has been documented by explorers and visitors to Glacier Bay (see Cooper, 1937; Field, 1975; Powell, 1980; for reviews and references). A large piedmont glacier filled Glacier Bay in 1794 when Captain George Vancouver surveyed the Pacific coast of North America (Fig. 8). This glacier was fed mainly by tongues of ice flowing down Muir and Tarr Inlets. The ice tongue in Tarr Inlet comprised a greatly expanded Grand Pacific Glacier and several large tributary glaciers (Margerie, Johns Hopkins, Lamplugh, Reid, Carroll and Rendu Glaciers). Between 1794 and the mid-1800s, Glacier Bay became deglaciated and the ice tongues in Muir and Tarr Inlets separated and began to retreat as independent entities (Fig. 8). In 1879, the ice tongue in Tarr Inlet terminated at the south end of Russell Island and could be properly termed Grand Pacific Glacier. Grand Pacific Glacier retreated $16 \mathrm{~km}$ to near the British Columbia-Alaska boundary between 1889 and 1912, and, in the process, lost contact with Margerie Glacier, the last of its Alaskan tributaries (Figs 8 and 9). It re-advanced c. $1 \mathrm{~km}$ in $1912-13$ and, since then, has fluctuated in a complex fashion, with the terminus located within $2 \mathrm{~km}$ of the international boundary.

Based on air-photograph analysis, we estimate that approximately $100 \mathrm{~km}^{3}$ of ice have been lost from Grand Pacific Glacier between its present terminus and Grand Pacific Pass in the last few hundred years. A much larger volume of ice, estimated at $250-400 \mathrm{~km}^{3}$, disappeared from Tarr Inlet and upper Glacier Bay between 1860 and 1912 , and an additional $100 \mathrm{~km}^{3}$ of ice also have been lost from Johns Hopkins, Queen and Rendu Inlets during and following this period.

Rapid deglaciation in this region has had important geomorphic and other effects. The upper Glacier BayTarr Inlet area is presently being uplifted at rates of up to $3 \mathrm{~cm}$ year $^{-1}$ due, at least in part, to the loss of ice during the last 200 years (Hudson and others, 1982). In addition, large amounts of unvegetated drift on recently deglaciated slopes in Melbern-Grand Pacific Valley are now being rapidly redeposited by mass wasting and fluvial processes along the margins of the glacier. Locally, steep rock slopes in this valley and along Tarr Inlet have cracked, sagged and slumped due to the loss of buttressing ice.

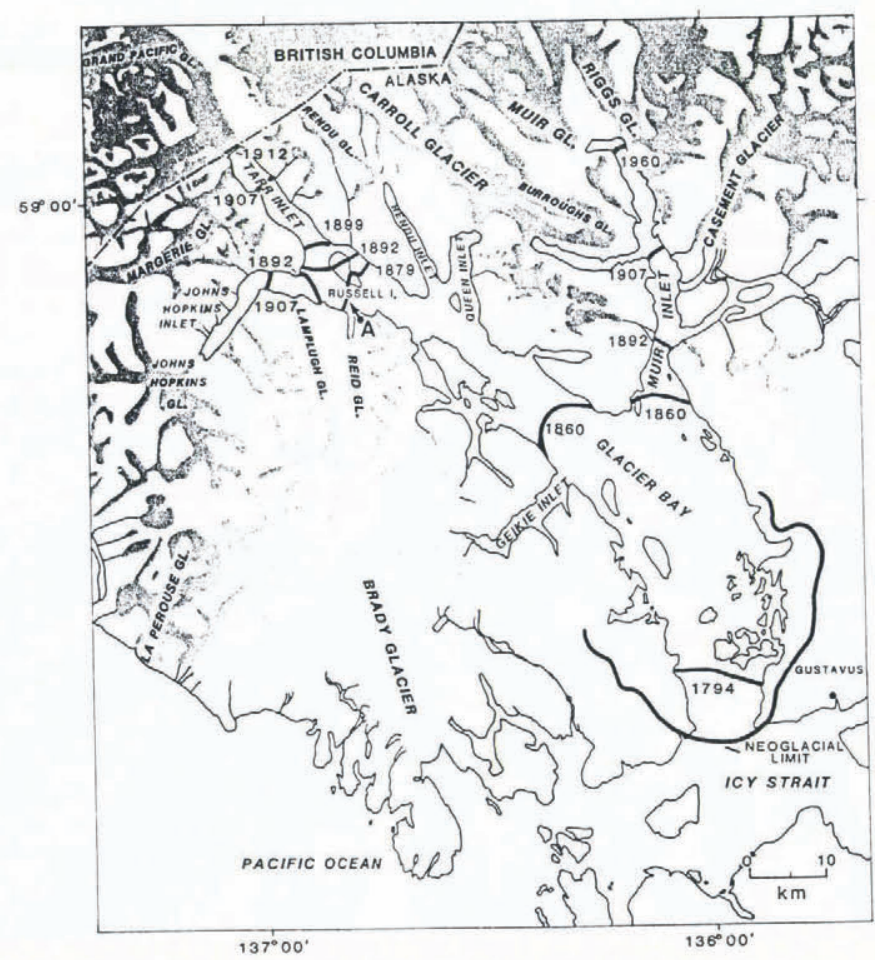

Fig. 8. Historic deglaciation of Glacier Bay and its inlets. Brown and others (1982); and references therein. $1860 i_{1}$ Data sources: Cooper (1937); Field (1975); Powell (1980); :e margin is approximate. $A$ is the viewpoint of Figure 9. 


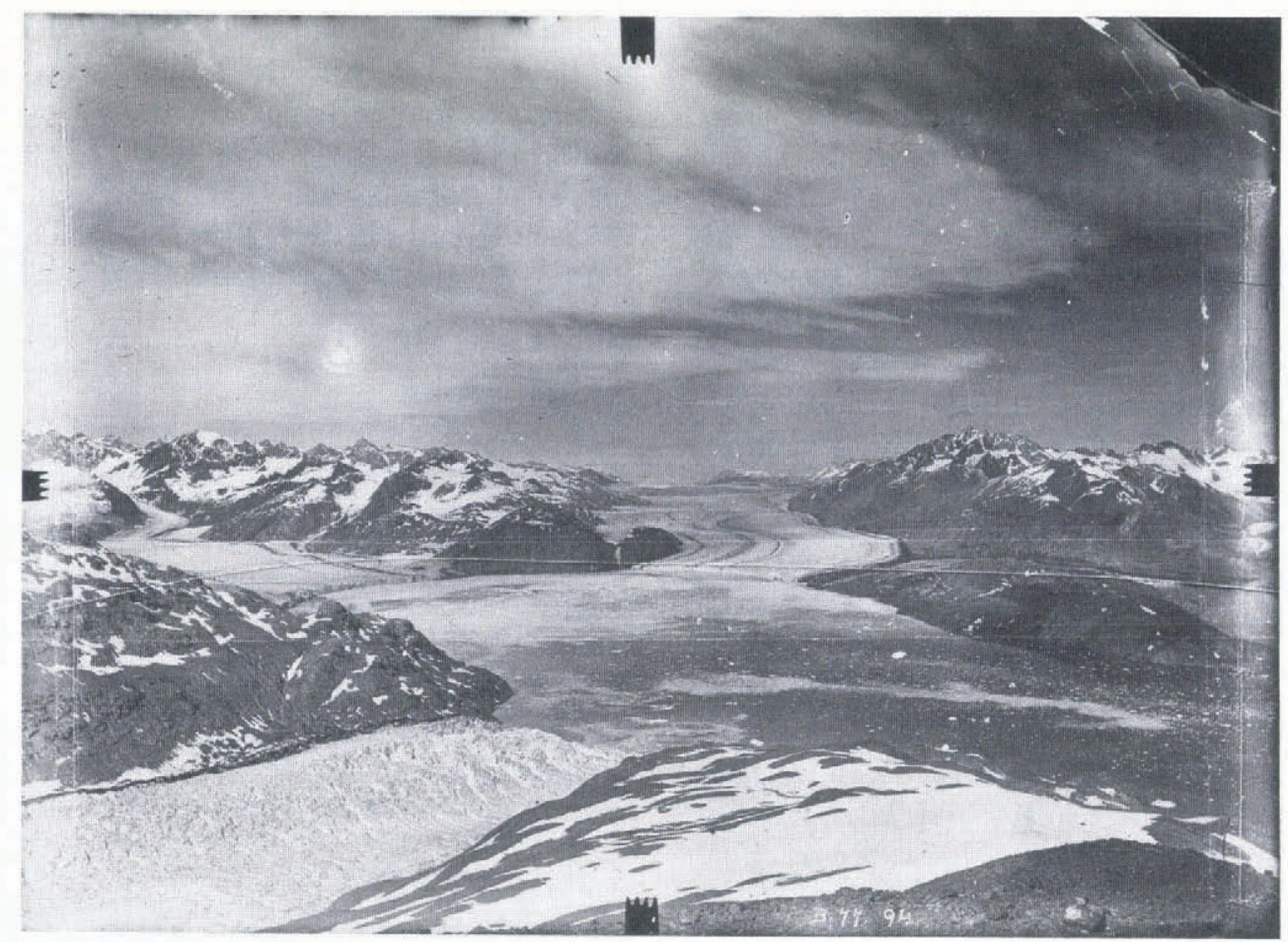

Fig. 9. The terminus of Grand Pacific Glacier (centre of photograph) in the vicinity of Russell Island in 1894 (see Figure 8 for location). View north-northwest from a ridge east of Reid Glacier (bottom left); Johns Hopkins Glacier is at the centre left, and Russell Island abuts the toe of Grand Pacific Glacier at the right. (Photograph by A.J. Brabazon (photograph station King; \#77); courtesy of International Boundary Commission, Ottawa, Canada.)

\section{DISCUSSION}

\section{Causes of retreat}

This paper has shown that two glaciers which share a common accumulation area, namely land-based Melbern Glacier and tide-water Grand Pacific Glacier, have had markedly different histories of retreat (Fig. 10). Glacier Bay and Tarr Inlet were deglaciated mainly in the 19th century, a time when Melbern Glacier was relatively stable and extensive. In contrast, much of the retreat of Melbern Glacier occurred during the 20th century.

Climatic warming in the last two centuries may be involved in the retreat of Melbern and Grand Pacific Glaciers but it does not explain their asynchroneity. Indeed, much of the retreat of Grand Pacific Glacier occurred prior to the warming of the late 1800 s and early 1900 s, and since 1912, the glacier periodically has advanced in spite of pronounced warming during the periods 1910-40 and 1975-present (Hansen and Lebedeff,

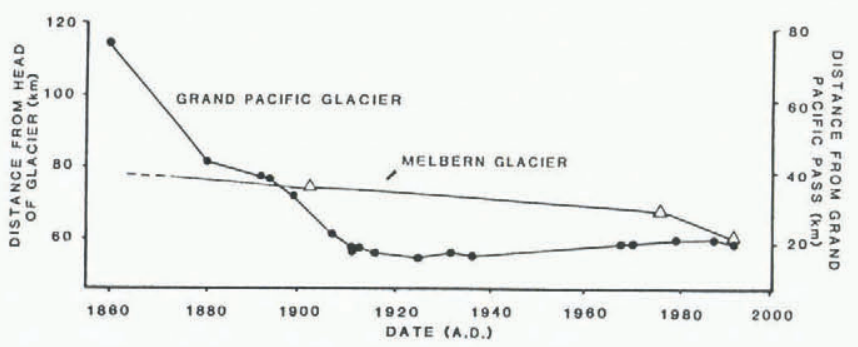

Fig. 10. Graphs summarizing the retreat of Melbern and Grand Pacific Glaciers since the mid-1800s. Data sources as in Figure 8, plus air-photograph observations and International Boundary Commission records.
1987). Such asynchronous retreat has been noted in other studies of glaciers in the region (e.g. Mann, 1986) and has been predicted on theoretical grounds (Mercer, 1961). The retreat of Grand Pacific Glacier was driven by calving in the deep waters of Glacier Bay and Tarr Inlet (Brown and others, 1982; Powell, 1988). Calving is a complex process that is controlled by non-climatic factors (Meier and Post, 1987). Calving rates of tide-water glaciers are high in deep water, generally exceeding ice flux to the terminus. Under such conditions, a glacier will retreat to a new equilibrium position, commonly a pinning point where water is shallower or the calving front is narrower, causing ice flow to accelerate. Grand Pacific Glacier attained such a position in 1912, with a relatively narrow calving front and probably a shallower grounding line.

During retreat, the average surface gradient of Grand Pacific Glacier increased south of Grand Pacific Pass. This may have shifted the ice divide between Grand Pacific and Melbern Glaciers northward, routing more ice southward from Grand Pacific Pass towards Tarr Inlet. There is, in fact, evidence for a recent shift in this ice divide. The Little Ice Age trim line of Grand Pacific Glacier between Grand Pacific Pass and the head of Tarr Inlet is $400-800 \mathrm{~m}$ above the present glacier surface. It increases in elevation south of Grand Pacific Pass, indicating that the ice divide was farther south at the maximum of the Little Ice Age than at present (perhaps in the vicinity of Ferris Glacier; Fig. 1). Presumably, as the ice divide moved north, less ice flowed into Melbern Valley, causing Melbern Glacier to retreat. Recession of Melbern Glacier was therefore delayed until after Grand Pacific Glacier equilibrated to its new calving-front position. 


\section{Analogy with late Pleistocene deglaciation}

Recent deglaciation of Melbern Valley is analogous to deglaciation of mountain valleys throughout British Columbia at the end of the Pleistocene (c. 14-10 ka BP). Melbern Valley is rapidly becoming deglaciated by thinning, stagnation and frontal retreat. The same style of deglaciation has been inferred for the end of the Pleistocene from studies of sediments and land forms in southern and central British Columbia (Fulton, 1967, 1991). Complex valley fills deposited at the close of the last glaciation and consisting largely of thick, icemarginal and proglacial lacustrine and fluvial sediments (Ryder and Clague, 1989; Ryder and others, 1991; and references therein) are similar to those that have accumulated in Melbern Valley during this century. Likewise, raised deltas and kame terraces identical to those in Melbern Valley are common late Pleistocene land forms throughout British Columbia. Even the scale of the recent and ancient deposits and land forms is similar: well over $100 \mathrm{~m}$ of 20 th century, ice-marginal sediments are present on the southeast flank of Pentice Ridge and west of Tikke Glacier, and the Tikke Creek terraces extend through a vertical range of more than $350 \mathrm{~m}$.

Similarly, historic deglaciation of Glacier Bay and Tarr Inlet is probably comparable, both in style and scale, to deglaciation of the coast of British Columbia at the end of the Pleistocene (e.g. Clague, 1985). In both instances, glaciers retreated rapidly by calving, probably triggered by climatic warming. About 14000 years ago, tongues of ice rapidly retreated across the British Columbia continental shelf to pinning points in fiords where they temporarily stabilized (Clague, 1985). Similarly, most of Glacier Bay was rapidly deglaciated in the 19th century, but ice margins stabilized and even advanced in some tributary fiords such as Tarr Inlet in the 20th century.

Finally, an analogy may also be drawn between the rapidity of late Pleistocene deglaciation and the recent retreat of Melbern and Grand Pacific Glaciers. Although the chronology of the advance and retreat of the Cordilleran ice sheet is not known in detail in most areas, available evidence suggests that individual valleys became ice-free rapidly at the close of the Pleistocene, probably over a period of several decades to a few hundred years (Clague, 1986). The Grand PacificMelbern Glacier system has lost over $300 \mathrm{~km}^{3}$ of ice, or more than $50 \%$ of its mass, in the last 200 years, most of this in the last 100 years. This may be comparable to rates of ice loss in Cordilleran valleys at the end of the Pleistocene.

\section{ACKNOWLEDGEMENTS}

We are grateful to Madame S. Jacques, International Boundary Commissioner (Canada), for allowing access to Commission documents. C. Gustafson (International
Boundary Commission, Canada-United States) assisted in locating key historical documents that contain information on the former extent of Grand Pacific and Melbern Glaciers. Reviews by R. M. Koerner (Geological Survey of Canada) and D.R. MacAyeal (University of Chicago) greatly improved the paper. This is Geological Survey of Canada Contribution No. 12592.

\section{REFERENCES}

Brown, C. S., M.F. Meier and A. Post. 1982. Calving speed of Alaska tide-water glaciers, with application to Columbia Glacier. U.S. Geol. Surv. Prof. Pap. 1258-C.

Clague, J.J. 1985. Deglaciation of the Prince Rupert-Kitimat area, British Columbia. Can. 7. Earth Sci., 22(2), 256-265.

Clague, J.J. 1986. The Quaternary stratigraphic record of British Columbia-evidence for episodic sedimentation and erosion controlled by glaciation. Can. F. Earth Sci., 23(6), 885-894.

Cooper, W.S. 1937. The problem of Glacier Bay, Alaska; a study of glacier variations. Geogr. Rev., $27(1), 37-62$.

Field, W. O. 1975. Glaciers of the St. Elias Mountains. In Field, W. O., ed. Mountain glaciers of the Northern Hemisphere. Vol. 2. Hanover, NH, Cold Regions Research and Engineering Laboratory, 143-297.

Fulton, R.J. 1967. Deglaciation studies in Kamloops region, an area of moderate relief, British Columbia. Geol. Surv. Can. Bull. 154.

Fulton, R.J. 1991. A conceptual model for growth and decay of the Cordilleran ice sheet. Géogr. Phys. Quat., 45(3), 281-286.

Hansen, J. and S. Lebedeff. 1987. Global trends of measured surface air temperature. 7. Geophys. Res., 92(D11), 13,345-13,372.

Hicks, S. D. and W. Shofnos. 1965. The determination of land emergence from sea level observations in southeast Alaska. 7. Geophys. Res., 70(14), 3315-3320.

Houghton, J.T., G.J. Jenkins and J.J. Ephraums, eds. 1990. Climate change; the IPCC scientific assessment. Cambridge, Cambridge University Press.

Hudson, T., K. Dixon and G. Plafker. 1982. Regional uplift in southeastern Alaska. U.S. Geol. Surv. Circ. 844, 132-135.

International Boundary Commission. 1928. International boundary between United States and Canada; from Cape Muzon to Mount St. Elias (Sheet No. 12). Ottawa, International Boundary Commission.

International Boundary Commission. 1952. Foint report upon the survey and demarcation of the boundary between Canada and the United States from Tongass Passage to Mount St. Elias. Ottawa, International Boundary Commission.

Mann, D.H. 1986. Reliability of a fjord glacier's fluctuations for paleoclimatic reconstructions. Quat. Res., 25(1), 10-24.

Meier, M.F. 1984. Contribution of small glaciers to global sea level. Science, 226(4681), 1418-1421.

Meier, M. F. and A. Post. 1987. Fast tide-water glaciers. F. Geophys. Res., 92(B9), 9051-9058.

Mercer, J.H. 1961. The response of fjord glaciers to changes in the firn limit. F. Glaciol., 3(29), 850-858.

Powell, R. D. 1980. Holocene glacimarine sediment deposition by tidewater glaciers in Glacier Bay, Alaska. (Ph.D. thesis, Ohio State University.)

Powell, R. D. 1988. Advance of glacial tide-water fronts in Glacier Bay, Alaska. In Milner, A. M. and J. D. Wood, Jr, eds. Proceedings of the Second Glacier Bay Science Symposium. Anchorage, AK, U.S. Department of the Interior. National Park Service, 67-73.

Ryder, J.M. and J.J. Clague. 1989. Quaternary stratigraphy and history. Area of Cordilleran ice sheet. British Columbia. In Fulton, R.J., ed. Quaternary geology of Canada and Greenland. Ottawa, Geological Survey of Canada, 48-58. (Geology of Canada 1.)

Ryder, J. M., R.J. Fulton and J.J. Clague. 1991. The Cordilleran ice sheet and the glacial geomorphology of southern and central British Columbia. Géogr. Phys. Quat., 45(3), 365-377.

The accuracy of references in the text and in this list is the responsibility of the authors, to whom queries should be addressed. 